\title{
Studies on effects of different sources and levels of zinc on growth and yield of cotton (Gossypium hirsutum L.) in salt affected soil
}

\section{S. SATHIYAMURTHI AND K. DHANASEKARAN}

Received : 04.10.2014; Revised : 07.11.2014; Accepted : 24.11.2014

\section{MEMBERS OF RESEARCH FORUM: \\ Corresponding author : S. SATHIYAMURTHI, Department of Soil Science and Agricultural Chemistry, Faculty of Agriculture, Annamalai University, Annamalai Nagar, CHIDAMBARAM (T.N.) INDIA}

Co-authors :

K. DHANASEKARAN, Department of Soil Science and Agricultural Chemistry, Faculty of Agriculture, Annamalai University, Annamalai Nagar, CHIDAMBARAM (T.N.) INDIA

\begin{abstract}
Summary
The present study was aimed to explore the effects of different sources and levels of zinc on growth and yield of cotton in saline sodic soil.A pot experiment was conducted in Factorial Completely Randomized Design with three replications. The treatments consisted of three different sources of zinc namely zinc sulphate, zinc-EDTA and zinc humate and four levels of $\mathrm{Zn}\left(0,1.25,2.5\right.$ and $\left.5.0 \mathrm{mg} \mathrm{kg}^{-1}\right)$. Cotton variety MCU-7 was grown as test crop. The growth parameters like plant height, leaf area index(LAI), number of monopodial branches plant ${ }^{-1}$, number of sympodial branches plant ${ }^{-1}$ and number of squares plant ${ }^{-1}$ and yield parameters like number of bolls per plant, boll weight were recorded at appropriate stages of crop growth. The seed cotton yield, lint yield and seed yield were recorded in each pot separately. The results of the study indicated that application of $\mathrm{Zn}$ significantly increased the growth and yield parameters of the cotton. Among the three sources, Zn-humate recorded the highest mean plant height, leaf area index, number of monopodial plant ${ }^{-1}$, number of sympodial plant $^{-1}$ and number of squares plant ${ }^{-1}$ as compared to other two sources. Highest yield parameter was recorded in the treatment supplied with $5 \mathrm{mg} \mathrm{kg}^{-1}$ of $\mathrm{Zn}$ as zinc humate. This was at par with the treatment applied with $2.5 \mathrm{mg} \mathrm{kg}^{-1}$ of $\mathrm{Zn}$ as zinc humate. This study concluded the application of $2.5 \mathrm{mg} \mathrm{kg}^{-1} \mathrm{Zn}$ as humate was established as the optimum dose of $\mathrm{Zn}$ to maximize the productivity of cotton in salt affected soil.
\end{abstract}

Key words : Cotton, Micronutrient, Zinc humate, Plant height, Seed cotton yield, Salt affected soils

How to cite this article : Sathiyamurthi, S. and Dhanasekaran, K. (2014). Studies on effects of different sources and levels of zinc on growth and yield of cotton (Gossypium hirsutum L.) in salt affected soil. Asian J. Soil Sci., 9(2): 284288. 